\title{
Indigenous Agricultural Practices and Adaptation Strategies Among Rural Farmers to Climate Change Incidence in Southwest, Nigeria
}

\author{
Adebayo, R.M ${ }^{1 *} \quad$ Adeoye, A.S ${ }^{2 *} \quad$ Omoyinmi, G.A.K ${ }^{1}$ \\ 1.Department of Agricultural Education, Federal College of Education (FCE), Osiele, Abeokuta. Ogun State, \\ Nigeria \\ 2.Department of Agricultural Extension and Rural Development, Federal University of Agriculture, Abeokuta. \\ P.M.B 2240. Abeokuta. Ogun State, Nigeria
}

\begin{abstract}
The prediction of climatic changes has the potential to severely affect rural farmers' livelihoods, resulting in food insecurity, among other consequences. This study aimed to assess the indigenous agricultural practices and adaptation strategies among rural farmers to climate change incidence in Southwest, Nigeria. Primary data on the socio-economic characteristics, farming activities of rural farmers that contribute to climate changes, indigenous adaptation practices and factors influencing the adoption of these adaptation strategies in the study area. Multistage sampling techniques were used for the study. Two (Oyo and Ogun) of the six states in southwest Nigeria was selected purposively for the study Structured interview guide was used to elicit information from the rural farmers. Data collected were analysed using descriptive and inferential statistics. Results revealed that above half (51.4\%) of the respondents were between 41-60years age range. The mean age of rural farmers was 53.5years. $69.2 \%$ were married, 75.6\% were Yoruba, 72.3\% had formal education, and 63.2\% of the rural farmers had between 11 25 years of farming experience with the mean farming experience of 22years. The main farming activities that contribute to climate changes were bush burning, continuous farming activities, overgrazing and use of fertilizer application. Majority $(85.7 \%)$ of the respondents utilize multiple/intercropping farming, 82.3\% utilize resistant varieties and $81.1 \%$ utilize mulching as indigenous adaptation strategies. Factors influencing the adoption of these adaptation strategies were shifting in planting date, access to extension service and training and indigenous knowledge practice. Regression result reveals that age, sex, household size and educational level were factors influencing the adoption of these adaptation strategies at $1 \%, 5 \%$ and $10 \%$ in the study area. The study concludes that various adaptation strategies were used by the rural farmers in response to altered farming resulting from experienced environmental degradation due to or similarly situated to events associated with climate change. It is therefore recommended that most of the strategies/practices currently used by rural farmers should be improved upon to ensure appropriate sustainable agricultural development in the country.
\end{abstract}

Keywords: Indigenous, Agriculture, Practices, Adaptation, Strategies, Climate Change, Southwest;

DOI: $10.7176 /$ JEES/10-7-03

Publication date:July $31^{\text {st }} 2020$

\section{Introduction}

Agriculture is known as the backbone of the Nigeria economy for both rural and urban dweller; it has become the main source of livelihood activities for many people in the country and beyond. Nevertheless, most of the agriculture in Nigeria hangs on rainfall and therefore inherently sensitive to climate conditions. According to Mubiru (2010) agriculture is projected that crop yields from rain-fed agriculture in some countries in Africa could be reduced by up to $50 \%$ by 2020 as a result of climate change. Climate is a key determinant of the status of Nigeria's natural resources, such as agriculture, forestry, water resources, wildlife, etc. According to World Bank (2008), agriculture contributes about half of the global emissions of two of the most potent non-carbon dioxide greenhouse gases: nitrous oxide and methane. FAO (2008) reported that agriculture contributes over $20 \%$ of global anthropogenic greenhouse gas emissions. Adaptation to climatic change is therefore critical and of concern in developing countries, particularly in Africa where vulnerability is high because the ability to adapt is low (Hassan $\&$ Nhemachena, 2008). In agriculture, adaptation helps farmers achieve their food, income and livelihood security objectives in the face of changing climatic and socio-economic conditions including climatic variability, extreme weather conditions such as droughts and floods and volatile short term changes in local and large-scale markets (Kandlinkar \& Risbey, 2000). Rural farmers can reduce potential damage by making a tactical response to climate changes and its impact.

According to Brussel (2007) adaptive measures to climatic change in agriculture range from technological solutions to adjustments in farm management or structures and to political changes such as adaptation plans. Therefore, changes in climate have consequences on the livelihoods of humans, animals, plants, and the ecosystems in a particular area. According to the Fourth Assessment Report of the United Nation's Intergovernmental Panel on Climate Change (IPCC, 2007), over the last century, atmospheric concentrations of 
carbon dioxide increased from a pre-industrial value of 278 parts per million (ppm) to $379 \mathrm{ppm}$ in 2005 and as a result the average global temperature rose by $0.74^{\circ} \mathrm{C}$. The IPCC report gives detailed projections for the $21 \mathrm{st}$ century and these show that global warming will continue and even accelerate. The best estimates predict that the earth could warm by $3^{\circ} \mathrm{C}$ by 2100 . IPCC considers Africa to be the most vulnerable to the impacts of climate change and variability. Adaptation is the adjustment in natural or human systems in response to actual or expected climate stimuli or their effects, which moderated harm or exploits beneficial opportunities (UNFCCC, 2007). Rural farmers' ability to adapt to the incidence of climate variation depends on factors such as wealth, technology, education, information, infrastructure, access to resources and management abilities from time to time. There is need to gain as much information as possible and learn the positions of the rural farmers and their needs about what they know about climate variation and change in order to offer adaptation practices that meet their needs (Lobell et.al, 2008).

The most dominant and widespread disaster due to climate change is drought, it has severely affected the agricultural sector in the country leading to influences such as famine, malnutrition, low production in crops and animals, among others. The reality facing the world is that the world has become warmer with the earth's surface temperature has risen by more than $0.7^{\circ} \mathrm{C}$ since the 1800 s (IPCC, 2007) causing long term changes in global climatic conditions. Studies have revealed that climate change will have long-lasting negative effects for populations and their environment in most parts of the world. Human health, food security, economic activities, physical infrastructure, and natural resources will be greatly undermined by the phenomenon (UNDP, 2007). In most parts of Africa; climate change will result in increased temperature, erratic rainfall, sea level rise, increased intensity and frequency of extreme weather events such as floods and droughts (Tadross et al., 2005). Climate changes in the country is expected to result in environmental degradation, increased water stress and low agricultural production which will result in livelihood and food insecurity for many rural citizens. Most of the constraints encountered by farmers in adaptation to climate change are associated with poverty (Deressa, 2008). For instance, lack of information to adaptation options could be attributed to the fact that research on climate change and adaptation options have not been reinforced in the country and this information is lacking and not reaching out to most areas. Lack of money hinders farmers from getting the necessary resources and technologies which assist in adapting to climate change. The agrarian rural poor farmers are the main target group for this study as they are at the receiving end of climate change impact. It is against this backdrop that the study intends to find answers to these following research objectives:

1. describe the socio-economic characteristics of rural farmers in the study area.

2. identify the farming activities of rural farmers that contribute to climate changes in the study area.

3. identify the indigenous adaptation practices been used by rural farmers in the study area.

4. identify factors influencing the adoption of these adaptation strategies in the study area.

\subsection{Hypotheses of the study}

Ho1: There is no significant relationship between the socio-economic characteristics of the rural farmers and the factors influencing the adoption of these adaptation strategies used by rural farmers.

\section{Methodology}

This study was carried out in southwest Nigeria, which covers Lagos, Ekiti, Ogun, Ondo, Osun and Oyo State mainly dominated by the Yoruba ethnic group. These groups were the largest ethnic group in the West African coast and one of the largest and longest established ethnic groups on the African continent. The total population of the area is 27,581,992 with Lagos state having 9,013,534; Oyo 5,591.598; Ondo 3,441,024; Osun 3,423, 535; Ogun 3,728,098 and Ekiti having 2,384212; (National Population Census 2006). The entire southwest lies in the humid tropical zone bordered by a mangrove swamp forest in the south. Major parts of the study area lie in the freshwater swamp forest and rain forest to the south, which turns to moist and dry woodland savannah towards the North. It has a land area of about 114,271square kilometers (about12\% of the total land mass of Nigeria, lying between latitude 40, 211 and 90, 231 North of the equator and longitude 20, 251 and 60, 311 East. The vegetation consists of a mixture of coastal vegetation and freshwater swamp forest, lagoon marsh and lowland rainforest vegetation in southwest and southeast of Ogun State; and the derived or savannah close canopy woodland that stretches from the western part of Ogun State to the northern parts of Oyo State. The savannah woodland covers over $60 \%$ of the entire area. Annual rainfall generally lies between $900 \mathrm{~mm}$ and $1500 \mathrm{~mm}$. The mean maximum temperature range is between $28 \mathrm{oC}$ and $36 \mathrm{oC}$ with February/March being the hottest months. Rainfall is the most important climatic factor critical to human survival. The rainforest zone of southwest Nigeria is characterized by an annual rainfall of about $2000-2500 \mathrm{~mm}$ and high humidity $(85 \%$ to $95 \%$ at a rainy season and $60 \%$ to or less at dry season). The wet season lasts between seven and nine months. These elements favor the cultivation of crops such as cassava, maize, sorghum, yams, rice, cocoyam, beans, etc. 


\subsection{Sampling procedure and sample size}

The populations of the study were the rural farmers (both men and women) in Southwest Nigeria. Multistage sampling techniques were used for the study. Two (Oyo and Ogun) of the six states in southwest Nigeria was selected purposively for the study because of the high number of rural farmers and their involvement in agricultural activities. From the two (2) States, there were eight (8) zones of Agricultural Development Programme in Ogun and Oyo States (OGADEP \& OYSADEP) respectively. Fifty percent (50\%) of the zones were randomly selected making a total of 4 zones for the study. The zones are (i) Ogun State (OGADEP): Ilaro and Abeokuta zones (ii) Oyo State (OYSADEP): Saki and Oyo zones. From each of the states selected, two local government areas were selected purposively. These two local governments were selected to be of different geographical zones. Therefore, four local communities were selected in the two states for detail adaptive strategies analysis. These communities cut across varying agro-climatic zones. The communities were selected based on the concentration of rural dwellers, size of farmland, involvement in farming and size of the community, open attitude to the research and years of settlement at the location. A total of Three Hundred and sixty (360) sample size was selected for the study. In the end, a total of $97.2 \%$ response rate was used for the analyses of data. Primary data for this study were collected through the use of a structured interview guide to obtained relevant information on the categories of the respondent. Descriptive and inferential statistics were used to analyze the data collected.

\section{Result and discussion}

\subsection{Socio-economic characteristic of the respondents:}

Result in Table 1 showed that above half (51.4\%) of the respondents were between 41-60years age range. The mean age of rural farmers was 53.5years. This reveals that the respondents used for this study were mainly elderly people and active farmers who have lived for a relatively long number of years in their community. The majority (69.2\%) of the respondents was married, $23.4 \%$ were widowed and $3.4 \%$ were divorced. Almost half $(48.8 \%)$ of the respondents practice Islamic religion, $41.3 \%$ practicing Christianity religion and $6.4 \%$ were Traditional religion worshippers. The result showed that the three religions are practicing in the study area. Ekong (2003) stated that religion entails a set of basic beliefs and ritualistic practices, although these belief and practice vary from one religion to another. Also, the majority (75.6\%) of the respondents were Yoruba, few (13.6\%) were Igede, 5.5\% Igbo, $1.7 \%$ were Hausa and $0.6 \%$ were Egun in the study area. It was noted that different type of ethnic groups such as Hausa, Yoruba, Igbo, Igede, and Egun are all living together peacefully in the study area. Above half, (53.2\%) of the respondents had a household size of between 5-9 persons with a mean household size of 6 persons. These results show that the rural inhabitants in southwest Nigeria maintain a relatively sizeable household which could serve as insurance against shortfalls in labor supply. The majority $(72.3 \%)$ of the respondents had a formal education in the study area, while $27.7 \%$ of the respondents had no formal education. This implies that majority of the respondents were literates, which is a factor in determining farmers adoption of improved technology as it is influenced by their level of education, It is projected that improved knowledge and farming experience will positively impact farmers' awareness and decision to take up adaptation measures to climate change. However, Maddison (2006) stated that educated and experienced farmers have more knowledge and information about climate change and agronomic practices that they can adopt in response. This implies that they are well aware of changes in climate, its consequence and all effort toward sustainable agriculture will be well appreciated. The majority (63.2\%) of the respondents had between 11-25 years of farming experience, The mean farming experience was 22 years. Most (83.9\%) of the respondents participating in farming activities as their major occupation. This agrees with Ekong (2010) which stated that rural dwellers in Nigeria have farming as their major livelihood activity. The data showed that above half (56.5\%) of the respondents earn between $\$ 10,001$ - $\$ 60,000$ as monthly income from their occupation in the study area. The mean income level was $\$ 36,896$. From the result, it could be observed that the rural dwellers are still struggling to have the basic necessity of life since they live on barely five dollars in a day and operate at small scale farming with manual tools, but very sensitive to climate changes. 
Table 1: Distribution based on socio-economic characteristics of the respondents $(n=350)$.

\begin{tabular}{|c|c|c|c|}
\hline Variable & Frequency & Percentages (\%) & Mean/stddev \\
\hline \multicolumn{4}{|l|}{ Age (years) } \\
\hline $21.0-40.0$ & 100 & 28.6 & \\
\hline $41.0-60.0$ & 180 & 51.4 & $53.5 / 13.76$ \\
\hline $61.0-80.0$ & 67 & 19.1 & \\
\hline $81.0-100.0$ & 3 & 0.9 & \\
\hline \multicolumn{4}{|l|}{ Marital status } \\
\hline Single & 14 & 4.0 & \\
\hline Married & 242 & 69.2 & \\
\hline Widowed & 82 & 23.4 & \\
\hline Divorced & 12 & 3.4 & \\
\hline \multicolumn{4}{|l|}{ Religion } \\
\hline Christianity & 151 & 41.3 & \\
\hline Islam & 176 & 48.8 & \\
\hline Traditional & 23 & 6.4 & \\
\hline \multicolumn{4}{|l|}{ Ethnicity } \\
\hline Hausa & 6 & 1.7 & \\
\hline Yoruba & 273 & 75.6 & \\
\hline Igbo & 20 & 5.5 & \\
\hline Igede & 49 & 13.6 & \\
\hline Egun & 2 & 0.6 & \\
\hline \multicolumn{4}{|l|}{ Household size } \\
\hline$<=4$ & 118 & 32.7 & \\
\hline $5-9$ & 192 & 53.2 & $6.15 / 3.24$ \\
\hline $10-14$ & 19 & 5.3 & \\
\hline $15-19$ & 21 & 5.8 & \\
\hline \multicolumn{4}{|l|}{ Educational level } \\
\hline No formal education & 100 & 27.7 & \\
\hline Primary education & 92 & 25.5 & \\
\hline Secondary education & 75 & 20.8 & \\
\hline Tertiary education & 64 & 17.7 & \\
\hline Adult education & 19 & 5.3 & \\
\hline \multicolumn{4}{|l|}{ Farming experience } \\
\hline$<=10.0$ & 40 & 11.1 & \\
\hline $11.0-25.0$ & 228 & 63.2 & $21.99 / 10.1$ \\
\hline $26.0-40.0$ & 70 & 19.4 & \\
\hline $41.0-55.0$ & 10 & 2.8 & \\
\hline $56.0-70.0$ & 2 & 6 & \\
\hline \multicolumn{4}{|l|}{ Primary occupation } \\
\hline Farming & 303 & 83.9 & \\
\hline Trading & 38 & 10.5 & \\
\hline Artisan & 9 & 2.5 & \\
\hline \multicolumn{4}{|l|}{ Income level } \\
\hline$<=10000$ & 79 & 21.9 & \\
\hline $10001-60000$ & 204 & 56.5 & \\
\hline $60001-110000$ & 58 & 16.1 & $36896.86 / 33114.89$ \\
\hline $110001-160000$ & 7 & 1.9 & \\
\hline $160001-210000$ & 2 & .6 & \\
\hline
\end{tabular}

\subsection{Farming activities of rural farmers that contribute to climate changes}

The result in Table 2 shows that the farming activities of the rural farmers that contribute to climate changes were bush burning with the mean value of 2.68 and ranked first among the activities of respondents that contribute to climate changes in the study area. Bush burning is generally the preferred traditional means of clearing farmland for seedbed preparation, which increases the concentration of greenhouse gases and particulate matter in the atmosphere (Wikipedia 2009). The International Federation of Organic Agriculture Movement (IFOAM) (2007) reports that conventional agricultural activities of farmers contribute to climate change because it applies excessive amounts of nitrogen fertilizer that is released as nitrous oxide and mines the earth of the nutrient needed to sustain production through rainforest clearing and slash and burn techniques that reduce carbon storage and release huge 
amounts of carbon dioxide from burning vegetation. Continuous farming activities of the rural farmer were with the mean value of 2.58 and ranked second among the activities of respondents that contribute to climate changes in the study area. Overgrazing was with the mean value of 2.27 and ranked third among the activities of respondents that contribute to climate changes in the study area. This could be attributed to the movement of cattle by the Fulani herdsmen in the southwest. The use of fertilizer was with the mean value 2.23 and ranked fourth among the activities of respondents that contribute to climate changes in the study area. The natural tendency would, therefore, be to increase the application of fertilizer in order to maintain soil fertility, which contributes to greenhouse gases. Burning of fossil fuel from vehicles, machines were with the mean value of 2.13 and ranked fifth among the activities of respondents that contribute to climate changes in the study area. Deforestation was with the mean value of 2.07 and ranked sixth among the activities of respondents that contribute to climate changes in the study area. Also burning of wood fuel for cooking was with the mean value 2.06 and ranked seventh among the activities of respondents that contribute to climate changes in the study area. With the widely reported rising poverty in Nigeria, especially among rural farming households, and the also rising prices of cooking gas and kerosene from time to time, burning of wood fuel as cooking energy has become the predominant practice to most rural farmers, not only in rural farming communities but also among the urban poor. Moreover, decreasing soil fertility is one of the extreme weather events that nearly all the farmers said it has been on the increase in the past ten years.

Table 2: Activities of rural farming towards climate change

\begin{tabular}{|c|c|c|c|c|}
\hline Activities of farmers towards climate & A (\%) & $\mathbf{O}(\%)$ & $\mathbf{N}(\%)$ & Mean \\
\hline Bush burning & $258(73.7)$ & $71(20.3)$ & $21(6.0)$ & 2.68 \\
\hline Continuous farming & $210(60.0)$ & $133(38.0)$ & $7(2.0)$ & 2.58 \\
\hline Overgrazing & $131(37.4)$ & $181(51.7)$ & $38(10.9)$ & 2.27 \\
\hline Burning of wood fuel for cooking & $82(23.4)$ & $208(59.4)$ & $60(17.1)$ & 2.06 \\
\hline The use of fertilizer & $130(37.1)$ & $172(49.1)$ & $48(13.7)$ & 2.23 \\
\hline Use of insecticides/pesticides & $82(23.4)$ & $126(36.0)$ & $142(50.6)$ & 1.83 \\
\hline Deforestation & $78(22.3)$ & $218(62.3)$ & $54(15.4)$ & 2.07 \\
\hline Burning of crop/household wastes & $98(28.0)$ & $143(40.9)$ & $109(31.1)$ & 1.97 \\
\hline Gases/chemical released from industries around & $30(8.6)$ & $109(31.1)$ & $211(60.3)$ & 1.48 \\
\hline High use of irrigation water & $42(12.0)$ & $113(32.3)$ & $195(55.7)$ & 1.56 \\
\hline Burning of fossil fuel from vehicles, machines etc & $93(26.6)$ & $211(60.3)$ & $46(13.1)$ & 2.13 \\
\hline Use of generators to generate electricity & $27(7.7)$ & $221(63.1)$ & $102(29.1)$ & 1.79 \\
\hline
\end{tabular}

Note: $A=$ Always, $\mathbf{O}=$ Occasionally, $N=$ Never.

\subsection{Indigenous adaptation strategies have been used by rural farmers}

The result in Table 3 shows that the majority $(85.7 \%)$ of the respondents utilize multiple/intercropping farming system in the study area. This is because different crops have different levels of resilience to weather variability; hence, planting many crops in a field could ensure that the rural farmer gets some output in the face of extreme weather situations. Benhin (2006) reports that growing a variety of crops on the same plot is an appropriate adaptation strategy for farmers because it helps to avoid complete crop failure as different crops may be affected differently by climate change. Hassan and Nkemechena (2008) had reported that increased diversification is a strong climate change adaptation measure. Most (82.3\%) of the rural farmer adapt to the use of resistant varieties in the study area. High yielding and fast growing crops can easily escape the caprices of climate change by completing their growth cycle before storm and drought sets-in, thereby checking the impact of climate change. Moreover, the use of heat tolerant and drought resistant crops are also effective adaptation practices (Downing et al. 1997). Most (81.1\%) of the respondents adopt the use of mulching in the study area. Increasing the use of organic matters such as mulch could avoid excessive soil moisture loss within the crop, increase soil aeration and soil moisture holding capacity. Most $(80.0 \%)$ of the respondents adopt moving to a different site in other to conserve and preserve the soil for another cropping season in the study area. Yirga (2007) reported that farmers often moved to fertile soils to ensure better yield and escape the vagaries of weather accessioned by climate change. The majority (71.4\%) of the respondent adopt the use of intensive manure/fertilizer application in the study area. Declining soil fertility is one of the land degradation sources that were overwhelmingly reported by rural farmer sampled to have been on the increase in the past years. Fertilizer application is therefore expected as an adaptation practice in order to maintain/increase soil fertility for most crops. The majority $(60.3 \%)$ of the respondents adopt the use of planting high yielding crop in the study area. High yielding and fast growing crops can easily escape the notions of climate change by completing their growth cycle before storm and drought sets-in or affect the performance of crop is grown. Furthermore, the use of heat tolerant and drought resistant crops are also effective adaptation practices most farmers utilize. 
Table 3: Indigenous adaptation strategies used by the rural farmer $(n=350)$

\begin{tabular}{lll}
\hline Adaptation strategies & Yes (\%) & No (\%) \\
\hline Mulching & $284(81.1)$ & $66(18.9)$ \\
Use of wetlands/river valleys (e.g. Fadama) & $72(20.6)$ & $278(79.4)$ \\
Contour cropping across slopes & $68(19.4)$ & $282(80.6)$ \\
Planting deeper than the usual planting depth & $101(28.9)$ & $249(71.1)$ \\
Planting high yielding crop & $211(60.3)$ & $139(39.7)$ \\
Intensive manure/fertilizer application & $250(71.4)$ & $100(28.6)$ \\
Increased weeding & $86(24.6)$ & $264(75.4)$ \\
Move to a different site & $280(80.0)$ & $70(20.0)$ \\
Changes in the timing of land preparation activities & $67(19.1)$ & $283(80.9)$ \\
Changes in planting dates & $62(17.7)$ & $288(82.3)$ \\
Changes in harvesting dates & $96(27.4)$ & $254(72.6)$ \\
Multiple cropping (planting of many crops in the same piece of land) & $300(85.7)$ & $40(14.3)$ \\
Mixed farming (crop and animal production) & $45(12.9)$ & $305(87.1)$ \\
Relay cropping- planting and harvesting in succession & $84(24.0)$ & $266(76.0)$ \\
Multiple/Intercropping system & $300(85.7)$ & $40(14.3)$ \\
Use of resistant varieties & $288(82.3)$ & $62(17.7)$ \\
Decreasing animal stock & $67(19.1)$ & $283(80.9)$ \\
Change from crop production to animal rearing & $62(17.7)$ & $288(82.3)$ \\
Change from animal production to crop production & $96(27.4)$ & $254(72.6)$ \\
Agro-forestry practice & $211(60.3)$ & $139(39.7)$ \\
Change from production to marketing of agricultural products & $45(12.9)$ & $305(87.1)$ \\
\hline
\end{tabular}

\subsection{Factors influencing the adoption of these adaptation strategies}

Result in Table 4 reveals that the majority $(63.7 \%)$ of the respondents indicate that shifting in planting date were major factors influencing the adoption of these adaptation strategies. Above half $(58.6 \%)$ of the respondents indicate that access to extension service and training, 58.3\% of the respondents indicate high inputs prices and problem of weather as the factors influencing the adoption of these adaptation strategies, above half $(56.6 \%)$ of the respondents indicate indigenous knowledge practice as factor influencing adoption of these adaptation strategies in the study area. The aim of an adaptation measure should be to increase the capacity of a system to survive external blows or change experienced by rural farmers. Climate change is projected to have greater negative impacts on poor farm households as they have the lowest capacity to adapt to changes in climatic conditions (Nhemachena \& Hassan, 2007). Adaptation measures are therefore significant to help these rural farmers and their communities to better face the hostile impacts and associated effects of climate change.

Table 4: Factor influencing the adoption of these adaptation strategies $(n=350)$

\begin{tabular}{lll}
\hline Factors influencing & Yes (\%) & No (\%) \\
\hline High inputs prices & $204(58.3)$ & $146(41.7)$ \\
High incidence of crop pest and diseases & $170(48.6)$ & $180(51.4)$ \\
Perception of household towards climate change & $148(42.3)$ & $202(57.7)$ \\
Drought tolerant varieties & $174(49.7)$ & $176(50.3)$ \\
Shifting planting date & $223(63.7)$ & $127(36.3)$ \\
Access to extension service and training & $205(58.6)$ & $145(41.4)$ \\
Conservative agriculture & $146(41.7)$ & $204(58.3)$ \\
Indigenous knowledge practice & $198(56.6)$ & $152(43.4)$ \\
Friends /family members & $137(39.1)$ & $213(60.9)$ \\
Government policy & $168(48.0)$ & $182(52.0)$ \\
Problem of weather & $204(58.3)$ & $146(41.7)$ \\
Access to fund/level of income & $146(41.7)$ & $204(58.3)$ \\
\hline
\end{tabular}

\subsection{Hypotheses of the study}

Ho 1: There is no significant relationship between the socio-economic characteristics of the rural farmers and the factors influencing the adoption of these adaptation strategies used by rural farmers.

The findings of the regression model in Table 5 indicate that age is negative and significantly (at 5\% and 10\% level) related to factors influencing the adoption of farmers' adaptive strategies to climate change. This is an indication that the probability of adaptation significantly decreases the older of a respondent. It can be projected that such farmers have less interest/incentives in taking note of climate change adaptation measures. Perhaps older farmers do not see the need to acclimatize to climate change effects in their agricultural activities. Furthermore, these older farmers may be more interested in following traditional methods rather than adopting modern farming 
techniques. The similar outcome has found and explained in the articles written by Acquah (2011) and Quayum \& Ali (2012). The regression model results explain that education is positive and significantly (at 5\% and $10 \%$ level) related to the factor affecting the adaptation strategies to climate change in the study area. This implies that the probability of adaptation to climate change is greater for those who have higher educational achievement compared to less-educated or illiterate farmers. It is obvious that educated farmers have more information, a greater ability to understand and respond to anticipated changes, able to forecast future consequences and, overall, have greater access to information and opportunities than others, which might encourage adaptation to climate change. Several studies found that education also positively and significantly affects the adoption of technology (Quayum \& Ali, 2012, Adeogun, Ajana, Ayinla, Yarhere and Adeogun, 2008). Household size is negatively and significantly (at the $10 \%$ level) related to factor influencing farmers' adaptation strategies to climate change effects. However, the negative sign on this relationship is contradictory to our initial hypothesis. This negative sign indicates that with increasing size of the family size, the probability of farmers' adoption of an adaptive strategy decreases. It was predictable that the sign of the variable household size would have a positive sign; the logic being that large family size makes available more labor which can actively involve in farming activities, better facilitating the adoption of adaptive measures against climate change effects, ceteris paribus. This supposition was in line with the results of similar work on climate change adaptation strategies done by Deressa et al., (2008, 2009), as well as the large body of literature on technology adoption such as Mignouna et al., (2011) and Tiamiyu et. al., (2009). Other studies, such as that of Quayum and Ali (2012) have shown that family size was negatively and significantly related to the adoption of technologies, but there is no definitive action shown in the literature reviewed for preparing this research work. There is a negative and significant (at 5\% level) relationship between farm size and factor influencing adaptation to climate change effects. Precisely, results show that increasing size of a farm operation decreases the probability of farmers' adoption of adaptive strategies to climate change in the study area. The reason behind this result may be the large farmers were deployed traditional technologies rather modern technologies to climate change adaptation. Moreover, large farms require greater levels of investment to implement adaptive strategies to climate change, therefore, farmers of the study failed to do that compared to a small farm. Acquah (2011) explained a similar result while farm size showed negatively significant with adaptation to climate change effects (Acquah, 2011). Moreover, larger farms require inputs such as seeds, fertilizer, pesticides, irrigation facilities, and more at rates which are stressors on farm budgets. The result of the logistic regression shows that positive and significant (at 5\% level) relationship between family income and adoption of adaptive strategies to climate change effects. This implies that farmers with high income are more likely to adopt adaptive strategies than farmers with lower incomes. The findings support projects undertaken by Government Organizations (GOs) and Non-Government Organizations (NGOs) designed to create off-farm livelihoods activities so that farmers can diversify and supplement their income and continue their agricultural operations in the face of climatic uncertainty. On the other hand, remittances and off-farm jobs might also be another source of annual family income of the farmers. Kim, Jung, Lee, Park and Takei, (2012) found that household income positively and significantly influences the adoption of adaptive to climate change (Kim, et. al.,., 2012), while Gbeibouo (2009) explained that wealthier farmers are more interested to adapt by changing planting practices, using irrigation, and altering the amount of land farmed (Gbetibouo, 2009). Further, Nhemachena and Hassan indicate that per capita income has a positive influence on farmers' decisions to take-up adaptation measures (Nhemachena \& Hassan, 2007).

The Durbin-Watson value of 1.1 shows that the errors in the regression model are independent. Some of the selected characteristics have a significant relationship with the outcome variable. This further affirms that factors influencing the adoption of some adaptation strategies used by the respondents are hinged on some of the socioeconomic characteristics of the rural farmers in the study area.

R2 = 0.047, Adjusted R2 = 0.019 Durbin Watson $=1.1$

Regression model

$Y=37.674-0.109 \times 1-0.002 \times 2+0.668 \times 3-0.463 \times 4+0.263 \times 5-0.098 \times 6+0.021 \times 7+0.001 \times 8+1.113 \times 9-$ $0.295 \times 10$

Where $\mathrm{X} 1=$ sex, $\mathrm{X} 2=$ age, $\mathrm{X} 3=$ marital status, $\mathrm{X} 4=$ religion, $\mathrm{X} 5=$ ethnicity, $\mathrm{X} 6=$ household size, $\mathrm{X} 7=$ educational level, $\mathrm{X} 8$ = farming experience, $\mathrm{X} 9$ = primary occupation and $\mathrm{X} 10$ farming size. 
Table 5: Test of Relationship between the Socio-Economic Characteristics and the factors influencing the adoption of these adaptation strategies used by rural farmers.

\begin{tabular}{lllll}
\hline & \multicolumn{2}{l}{ Unstandardized Coefficients } \\
B & Std. Error & $\begin{array}{l}\text { Standardized Coefficients } \\
\text { Beta }\end{array}$ & t-value \\
\hline (Constant) & 37.674 & 1.788 & & 21.069 \\
Sex & .109 & .534 & .011 & .205 \\
Age & -.002 & .019 & -.005 & $-.085^{* *}$ \\
Marital status & .668 & .365 & .099 & $1.827^{*}$ \\
Religion & .463 & .413 & .062 & 1.122 \\
Ethnicity & .263 & .353 & .040 & .746 \\
Household size & -.098 & .079 & .068 & $1.235^{*}$ \\
Educational level & .021 & .210 & .005 & $.098^{* *}$ \\
Farming experience & .001 & .025 & .003 & .058 \\
Primary occupation & 1.113 & .597 & .102 & $1.862^{*}$ \\
Farm size & -.295 & .138 & -.116 & $-2.133^{* *}$ \\
R-value & 0.218 & & & \\
R square & 0.047 & & & \\
Adjusted R square & 0.019 & & & \\
Durbin-Watson & 1.104 & & & \\
\hline
\end{tabular}

Ho 2: There is no significant relationship between socio-economic characteristics of rural farmers and the activities of rural farmers that contribute to climate change in the study area.

The result in Table 6 shows the result of the test of relationship between in the socio-economic characteristics of rural farmers and the activities of rural farmers that contribute to climate change in the study area. Chi-square and Pearson's Product Moment Correlation (PPMC) analysis was used to analysed the data. Chi-square analysis showed that there is a significant relationship $(\mathrm{P}<0.05)$ between $\operatorname{sex}\left(\chi^{2}=11.102\right)$, marital status $\left(\chi^{2}=9.222\right)$, educational level $\left(\chi^{2}=11.503\right)$, primary occupation $\left(\chi^{2}=16.406\right)$ and the activities of rural farmers that contribute to climate change in the study area. The implication of this is that sex, marital status and level of education of the rural farmers will have effect on the activities of rural farmers that contributes to climate changes in the study area. Furthermore, the correlation analysis in Table 7 reveal that a significant relationship $(\mathrm{p}<0.05)$ exist between age $(r=0.035)$ household size $(r=0.001)$ and the activities of rural farmers that contribute to climate change in the study area. Therefore it can be deduced that the age and household size of the respondents will have greater influence on the activities of rural farmers that contribute to climate change in the study area.

Table 6: Chi-square result of the socio-economic characteristics of the rural farmers and the activities of rural farmers that contribute to climate change in the study area.

\begin{tabular}{lllll}
\hline Variables & $\boldsymbol{\chi}^{\mathbf{2}}-$ value & Df & p-value & Decision \\
\hline Sex & 11.102 & 1 & 0.049 & $\mathrm{~S}$ \\
Marital status & 9.222 & 3 & 0.026 & $\mathrm{~S}$ \\
Religion & 1.889 & 2 & 0.596 & $\mathrm{NS}$ \\
Ethnicity & 1.693 & 4 & 0.792 & $\mathrm{NS}$ \\
Educational level & 11.503 & 4 & 0.021 & $\mathrm{~S}$ \\
Primary occupation & 16,406 & 2 & 0.012 & $\mathrm{~S}$ \\
Secondary occupation & 0.496 & 6 & 0.078 & $\mathrm{NS}$ \\
Member of association & 0.659 & 1 & 0.417 & $\mathrm{NS}$ \\
\hline
\end{tabular}

Table 7: Correlation result of socio-economic characteristics of the rural farmer and the activities of rural farmers that contribute to climate change in the study area.

\begin{tabular}{llll}
\hline Variables & r-value & p-value & Decision \\
\hline Age & 0.035 & 0.017 & $\mathrm{~S}$ \\
Household size & 0.001 & 0.028 & $\mathrm{~S}$ \\
Farming experience & -0.014 & 0.796 & $\mathrm{NS}$ \\
Income level & -0.035 & 0.508 & $\mathrm{NS}$ \\
\hline
\end{tabular}

\subsection{Conclusion and Recommendation}

\subsection{Conclusion}

The demographic attributes of rural farmers have an influence on their factors influencing adaptation strategies to climate change. Farmers in the area of study rely on rain-fed agriculture while considering risky, mono-cropping practicing under dry land. Sex, marital status, educational level and primary occupation were found to promote adaptation strategies in the study area. This implies that education to improve awareness of the potential benefits of adaptation is an important policy measure. Various adaptation strategies were used by the farmers in response 
to altered farming resulting from experienced environmental degradation due to or similarly situated to events associated with climate change. Adaptation strategies in order by importance finding that multiple/intercropping farming, use of resistant varieties, mulching and so on were utilized by rural farmers. It is evidenced from this study that rural farmers are experiencing a change in climate and they have already devised a means to survive. It is from this point that the policy of reliable and effective measures of adaptation need to be implemented and must be accessible to the end users. The low adaptive capacity among the rural farmers makes them more vulnerable to the impacts of climate change. Such indigenous adaptation strategies need to be supported by relevant policies that enhance climate change adaptation at various levels. The study has shown that almost all respondents sampled are involved in agricultural production as their main source of livelihood. This suggests that when agricultural activities are impacted by climate change it may have serious consequences on their households' food security and general livelihoods. The logistic regression model explained that out of ten selected factors, six of them (age, marital status, household size, educational level, primary occupation, and farm size) were statistically significant factors in relation to factors influencing the adoption of adaptive strategies. Therefore, we conclude that these six factors can be identified as influential characteristics of rural farmers who adopt coping strategies to climate change effects.

\subsection{Recommendation}

Based on these findings, it was recommended that the following should be implemented in the study area:

1. Climate change awareness is still very much needed among rural farmers, and in doing so, data should be disaggregated and disseminated at the community level, putting into consideration demographic factors, especially gender issues when address climate change impact.

2. Policies must aim at promoting farm-level adaptation through an emphasis on the early warning systems and disaster risk management and also, effective participation of rural farmers in adopting better agricultural and land use practices

3. Rural Farmers should be given more support from both Local, State and Federal Government as well as NonGovernmental Organizations in terms of training, information and knowledge sharing about climate changes and its adaptation.

4. Most of the strategies/practices currently used by rural farmers should be improved upon to ensure appropriate sustainable agricultural development in the country.

4. There is a need to promote systems such as agroforestry and conservation agriculture that promote ecosystem services.

5. Farmers who practice environmentally friendly adaptation strategies can be paid or compensated (carbon trading) for their initiative as a way of encouraging other farmers to do the same or they can be assisted with highbreed seeds (tolerant to drought and fast growing) and subsidized agricultural inputs from NGOs and the government.

6. There is a need by agricultural extension and economists department to design strategies that could help the farmers/rural communities' responses effectively to global warming.

\subsection{Acknowledgement}

The research team genuinely registers our deep appreciation to Tertiary Education Trust Fund (TETFUND) Abuja. The provost Federal College of Education Osiele, Ogun State Nigeria, Dr A.A Ajayi, the management team and the TETFUND Desk Officer, Mr A. A. Abati for granting us the endorsement and release of fund to carry out this research work titled "Assessment of Indigenous Agricultural Practices and Adaptation to Climate Change among Rural Farmers in South West, Nigeria". Finally we thank our respondent (rural farmer), extension agents and field enumerators in both Ogun and Oyo state for their co-operation and support. We also wish to thank two (2) anonymous reviewers for their very useful contribution, correction and comments which helped to bring the paper to the present level.

Sponsored by:

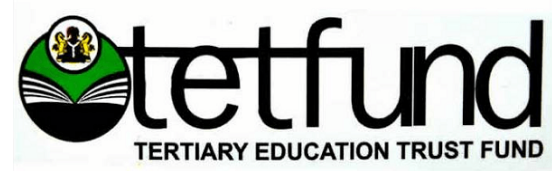

\section{References}

Acquah, H.D. Farmers' perception and adaptation to climate change effects: A willingness to pay. J. Sustain. Dev. Afr.2011, 13, 150-161.

Adeogun, O.A.; Ajana, A.M.; Ayinla, O.A.; Yarhere, M.T.; \& Adeogun, M.O. (2008). Application of logit model in adoption decision: A study of hybrid clarias in Lagos State, Nigeria. Am.-Eurasian J.Agric. Environ. 
Sci.2008, 4, 468-472.

Benhin, J. K. A. (2006). Climate change and South African agriculture: Impacts and adaptation options. CEEPA Discussion Paper No. 21. Centre for Environmental Economics and Policy in Africa, University of Pretoria.

Brussel, S. E. C. (2007). Adapting to climate changes: the challenge for European agriculture and rural areas. Commission of the European communities. Commission working staff working document accompanying the white paper No. 147;2009.

Deressa, T.; Hassan, R. M.; Alemu, T.; Yesuf, M. \& Ringler, C. (2008). Analyzing the Determinants of Farmers' Choice of Adaptation Methods and Perceptions of Climate Change in the Nile Basin of Ethiopia; IFPRI Discussion Paper 00798; International Food Policy Research Institute (IFPRI): Washington, DC, USA, 2008.

Downing, T. E., L. Ringius, M. Hulme \& D. Waughray (1997). Adapting to Climate Change in Africa'. Mitigation and Adaptation Strategies for Global Change Vol. 2: 19-44.

Ekong E. E. (2010). Rural sociology. Dove Educational Publishers, Uyo.

Ekong, E. E. (2003). An Introduction to Rural Sociology (2nd Edition), Uyo: Dove Education Publishers. pp. 341 $-395$.

FAO. (2008). Climate Change Adaptation and Mitigation: Challenges and Opportunities for Food Security. Rome, Italy.

Gbetibouo, G.A. (2009). Understanding Farmers' Perceptions and Adaptations to Climate Change and Variability: The Case of the Limpopo Basin, South Africa; IFPRI Discussion Paper; International Food Policy Research Institute (IFPRI): Washington, DC, USA, 2009. Available online: http://Www.Ifpri.Org/Sites/Default/Files/Publications/Ifpridp00849.Pdf (accessed on 13 July 2012).

Hassan, R. \& Nhemachena, C. (2008). Determinants of African farmers' strategies for adapting to climate change: multinomial choice analysis. AFJARE, 2(1): 85-104.

IFOAM. (2007). Organic agriculture's role in countering climate change. IFOAM, Germany.

Intergovernmental Panel on Climate Change (IPCC). Climate Change 2007: Impacts, Adaptation, and Vulnerability: An Assessment Report of the Intergovernmental Panel on Climate Change; Cambridge University Press: Cambridge, UK, 2007.

Kandlinkar, M \& Risbey, J, (2000). Agricultural impacts of climate change: If adaptation is the answer, what is the question? Climatic Change 45, 529-39.

Kim, C.; Jung, H.; Lee, S.; Park, S.; Takei, A.An analysis on determinants of farmers' adaptation to climate change in Korea.J. Rural Dev. 2012, 35, 53-72.

Lobell, D. B., Burke, M. B., Tebaldi, C., Mastrandrea, M. D., Falcon, W. P., \& Naylor, R. L. (2008). Prioritizing climate change adaptation needs for food security in 2030. Science $319,607-610$.

Maddison, D. (2006). The Perception of and Adaptation to Climate Change in Africa. CEEPA Discussion Paper No. 10, University of Pretoria, South Africa.

Mubiru, D. N. (2010). Climate change and adaptation options in Karamoja sub-region. European commission. Humanitarian aid. National Agricultural Research Organization [NARO]/ National Agricultural Research Laboratories - Kawanda Pp 1-24.

National Population Commission (2006). Population and Housing Census of the Federal Republic of Nigeria. Analytical Report at the National Population Commission, Abuja, Nigeria.

Nkemachena, C. \& Hassan, R., (2007). Micro-Level Analysis of Farmers' Adaptation to Climate Change in Southern Africa. IFPRI Discussion Paper 00714 August, Washington DC: International Food Policy Research Institute. United Nations Framework Convention on Climate Change

Quayum, M.A. \& Ali, A.M. (2012). Adoption and diffusion of power tiller in Bangladesh. Bangladesh J. Agric. Res.2012, 37, 307-325.

Tadross, M. A., Jack C, \& Hewitson B. C. (2005). On RCM-based projections of change in southern African summer climate. Geophysical Research Letters 32(23): L23713.1-L23713.4.

United Nations Development Program, (2007). Fighting Climate Change. Human Development Report 2007, 5th Edn., Palgrave Macmillan, New York, ISBN-10: 0230547044, pp: 384.

United Nations Framework Convention on Climate Change (UNFCCC). (2007). Climatic Change Impact, Vulnerabilities, and Adaptation in Developing Countries UNFCCC Secretariat, MartinLuther-King-Straat 8 53175 Bonn, Germany. www.unfecc.int.

Wikipedia, (2009). "Climate change and agriculture." Retrieved September 09, 2009, from http://www.en.wikipedia.org/wiki/.

World Bank (2008). Agriculture for Development Policy Brief: Adaptation and mitigation of climate change in agriculture. World Development Report 2008 Retrieved March 8, 2010, from http://www.steresources.worldbank.org/INTWDR.

Yirga, C. T. (2007), 'The Dynamics of Soil Degradation and Incentives for Optimal Management in the Central Highlands of Ethiopia'. Ph.D. Thesis. Department of Agricultural Economics, Extension and Rural Development, University of Pretoria, South Africa. 